\title{
Quality of life in blind and partially sighted people
}

(IIIIIIIIIIIIIIIIIIIIIIIIIIIIIIIIIIIIIIIIIIIIIIIIIIIIIIIIIIIIIIIIIIIIIIIIIIIIIIIIIIIIII

1 Gorka Vuletić

2 Tea Šarlija

3 Tomislav Benjak

1 Departmant of Psychology, Faculty of humanities and social sciences, University in Osijek Lorenza Jägera 9, 31000 Osijek, Croatia

2 Social Welfare Centre Donji Miholjac, Vukovarska 7, 31540 Donji Miholjac, Croatia

3 Croatian Institute of Public Health Rockefellerova 7, 10000 Zagreb, Croatia

\footnotetext{
Abstract

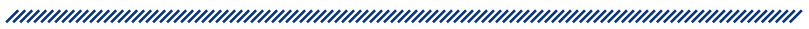

The aim of this research was to examine the subjective quality of life in blind and partially sighted people in relation to the type of impairment, duration of impairment and participation in psychosocial rehabilitation. The study used a sociodemographic and health questionnaire, and the Personal Wellbeing Index for adults to examine participant satisfaction with different life domains. The results have shown that subjective quality of life in blind and partially sighted people is within the theoretically expected normative range for global population of 60 to $80 \%$ scale maximum. The results have also shown that type and duration of impairment as well as participation in psychosocial rehabilitation are significant indicators of subjective quality of life of blind and partially sighted people.
}

Key words: visual impairment, blindness, low vision, subjective quality of life, duration of impairment, psychosocial rehabilitation

Article received: 13.01.2016.

Article accepted: 17.10.2016.

Corresponding author:

dr. sc. Tomislav Benjak

Croatian Institute of Public Health

Rockefellerova 7, 10000 Zagreb, Croatia

Phone: (01) 4863313

E-mail: tomislav.benjak@hzjz.hr

\section{Introduction}

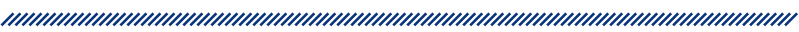

Visual impairments include blindness and low vision. The degree of visual impairment is determined by the residual visual acuity and breadth of visual field, based on which blindness and low vision are defined in categories. There are different definitions of visual impairments, as there are different criteria on what is considered blindness, and what low vision ${ }^{1}$, but the categorization of visual impairment currently in use worldwide is based on the International Classification of Diseases 10th Revision (ICD 10) ${ }^{2}$. According to estimates by the World Health Organization ${ }^{3}$ there are 285 million people in the world with visual impairment, of which 39 million are blind, and thus the prevalence of visual disorders is 
around $4 \%$ and blindness around $5 \%$. Epidemiological studies, about visual impairment, in Europe show that there are still many countries suffering from lack of available data on prevalence, incidence, and causes of visual impairment in children as well as in the whole population ${ }^{4}$. In Croatia, the data about persons with severe visual impairments that are followed in the Registry of Persons with Disabilities and recorded prevalence of blindness is $1 \%$ which is less than the above estimate $^{5}$. In accordance with the UN Convention on the Rights of Persons with Disabilities ${ }^{6}$ it is necessary to encourage and improve the implementation of research about disabilities, including visually impaired people.

By 1980 , a series of studies in the field of visual impairments and rehabilitation were conducted. Most focused on objective tasks, specific measurements of functional capacities (reading speed) and the pleasure in helping persons with visual impairments. Said measures did not encompass all important life domains so the research gradually focused on quality of life ( $Q \circ L)$ as the consequence of psychosocial rehabilitation of persons with visual impairments. Another important reason for measuring QoL is an increased interest by the government and health organizations in acquiring the results of health care and assistance quality?

Research into the quality of life of the visually impaired is scant. Mostly, these are clinical studies analysing traditional indicators of visual impairments such as visual acuity and visual field. Despite the few published studies, a need exists for measuring the QoL of the blind and partially sighted. Such research should compare the two against healthy population to document the consequences of visual impairments, as well as broader than just clinical results ${ }^{8}$.

As visual impairments can have negative effects on the QoL and, by extension, on building up skills and selfreliance, measuring and promoting the quality of life of the visually challenged (education, social life, health, rehabilitation programs) have become a priority ${ }^{8}$. However, they are only a priority in wealthy countries, which is why it is only there that diverse research into the QoL of the blind and partially sighted is carried out, first and foremost in the US, where several instruments have so far been used and validated ${ }^{9}$. Langelaan, de Boer, et al. ${ }^{10}$ compared in their study the QoL of healthy sighted population and blind and partially sighted individuals. Results have shown that the latter had more problems in every aspect of life, and, consequently, a lower QoL than the former. QoL of the visually impaired was also compared against the QoL associated with other chron- ic diseases. Obtained results showed that the former group had lower QoL than persons suffering from type Il diabetes and hearing impairments, but higher than persons who suffered from a stroke, multiple sclerosis, depression and mental disease.

Blindness and low vision alone may reduce life quality, but can also be associated with certain age, sex, personality traits, rehabilitation process and comorbidity. Individuals who have become blind in war, for example, due to an explosion, often also suffer from loss of an extremity ${ }^{11}$. Research by Pey, Nzegwu and Dooley ${ }^{12}$ has shown that partially sighted persons tend to be more ambulatory and leave the house more often that blind individuals, encounter far less difficulty in leaving the house on their own than blind persons. The study has shown that partially sighted persons face fewer problems than the blind in making friends, fulfilling life roles, as well as feel less socially isolated. When talking about overall quality of life, said study yielded the finding that the partially sighted have a higher QoL than the blind. Massof ${ }^{13}$ states that the main difference between the blind and the partially sighted population is that the former see their blindness as their characteristic trait, while the latter try to function as if they had healthy sight. Though blindness directly affects the QoL, when it comes to impairment duration (congenital or acquired blindness), facing blindness falls easier on persons blind from birth or an early age ${ }^{11}$. Several studies tackled cases of blindness acquired due to an illness, such as diabetes, or due to an accident. Said studies report worsened QoL ${ }^{14}$. Research by Thurston ${ }^{15}$ on blind and partially sighted persons who grew blind later in life corroborated the results of other studies, that is, demonstrated that loss of sight had a negative impact on the disposition and quality of life. Likewise, many subjects felt socially isolated. The main purpose of psychosocial rehabilitation is to elevate $\mathrm{QoL}^{11}$. Langelaan, van Nispenet al. ${ }^{16}$ found that quality of life mostly improved within one year after psychosocial rehabilitation and that age was a predictor of QoL. The younger the patient, the higher the QoL after psychosocial rehabilitation ${ }^{11}$. Research has shown that tackling daily activities is one of the biggest problems for the blind and partially sighted. Psychosocial rehabilitation is thus one of key factors for the coping of the visually impaired in developed countries ${ }^{7}$. For a person to be independent, certain prerequisites must be met, one of the most important being the ability to independently run daily errands. This is a special problem for persons with visual impairments ${ }^{17}$. 
The purpose of this study was to multidimensionally explore QoL of the blind and partially sighted persons regardless of the visual impairments complicating their everyday life and affecting their quality of living.

\section{Method}

\section{Participants}

The study included 142 participants with visual impairments ( 78 blind and 64 partially sighted persons). Of the overall number, 69 had congenital visual impairments, 73 acquired.

Regarding the region of living, 45 were members of the Osijek-Baranja Association of Blind Persons, 30 members of the Zagreb Association of Blind Persons and 13 members of the Koprivnica-Križevci Association of Blind Persons. Fifty-four respondents filled out an online questionnaire. Eighty-five subjects were men and 57 women of $18+$ age; by age group: 48 participants were aged 18-40, 58 were between 40 and 60 , and 36 were in the $60+$ category.

\section{Measures}

The following measuring instruments were used:

\section{Socio-demographical and health questionnaire}

The questionnaire was designed for the specific needs of this study. It contains questions about respondent socio-demographics (sex, age, education, employment and marital status, and residence) and visual impairments (vision status, impairment duration - congenital or acquired, use of aids, knowledge of the Braille and participation in psychosocial rehabilitation). (Table 1.)

\section{Personal Wellbeing Index ${ }^{18}$ (PWI - A)}

Personal Wellbeing Index - Adult Questionnaire ${ }^{18}$; PWI-A, comprises seven subscales of self-assessed satisfaction across seven domains: standard of living, health, achievements in life, close relationships, safety, community connectedness and future security. Answers are given on an 11-point Likert scale where 0 denotes complete dissatisfaction and 10 complete satisfaction. Overall index (PWI) is expressed as an arithmetic mean of the results in the seven subscales. For the purpose of creating results that can be simply compared with one another, recommendation is to convert all data to a standard form, on a $0-100$ point scale. Thus index is presented in the form of percentage of scale maximum (\%SM), as well as domain scores.

PWI has good psychometric properties. As regards construct validity, the seven domains constitute the minimum set of domains that represent the first level deconstruction of 'life as a whole'. The combination of the unique and shared variances across the seven domains typically explains about 30-60 percent of the variance in 'satisfaction with life as a whole'. The seven domains also consistently form a single stable factor and account for about $50 \%$ of the variance in Australia and other countries ${ }^{19}$.As regards convergent validity, according to Thomas ${ }^{20}$ a correlation of .78 with the 'satisfaction with life' scale has been reported $^{20}$. Reliability analysis has produced a maximum variation of 3.2 percentage points in subjective wellbeing. Cronbach alpha lies between .70 and .85 in Australia and overseas. Inter-domain correlations are often moderate at round .30 to .55 and item-total correlations are at least .50. The index has also demonstrated good test-retest reliability across one-two week intervals with an intra-class correlation coefficient of .84. Sensitivity analysis indicates a level of sensitivity between demographic groups that is consistent with the theory of subjective wellbeing homeostasis. This applies both in Australia and other countries ${ }^{18}$.

Suitability of instruments for the blind and partially sighted population: For the purpose of this study, questionnaires were printed in black print, in Braille. An additional online questionnaire was made and will be discussed under research procedure. It should be pointed out that the sociodemographic and health questionnaire has an ageadjusted category for the visually challenged to fill out. Respondents were asked to solely mark their age group, choosing from the three given. Consequently, a share of descriptive statistics (age average) has been sacrificed, but the changes were necessary as age specification would have caused unwarranted complications for the interviewees. 


\section{Results}

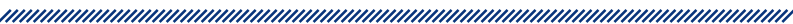

Socio demographic characteristics are presented in Table 1.

\begin{tabular}{|c|c|c|c|}
\hline \multicolumn{4}{|c|}{$\begin{array}{l}\text { Table } 1 \text {. The frequencies and percentages } \\
\text { of vision status, impairment duration } \\
\text { - congenital or acquired, education, } \\
\text { employment, marital status and } \\
\text { participation in psychosocial rehabilitation } \\
\text { (N = 142) }\end{array}$} \\
\hline Variable & & $\mathrm{N}$ & $\%$ \\
\hline \multirow{2}{*}{ Vision status } & Partially sighted & 64 & 45,1 \\
\hline & Blind & 78 & 54,9 \\
\hline \multirow{2}{*}{$\begin{array}{l}\text { Impairment } \\
\text { duration }\end{array}$} & Congenital & 69 & 48,6 \\
\hline & Acquired & 73 & 51,4 \\
\hline \multirow{6}{*}{ Education } & $\begin{array}{l}\text { Less than primary } \\
\text { education }\end{array}$ & 1 & 0,7 \\
\hline & Elementary school & 11 & 7,7 \\
\hline & Secondary school & 93 & 65,5 \\
\hline & Cooperative education & 4 & 2,8 \\
\hline & $\begin{array}{l}\text { Higher school/ } \\
\text { education }\end{array}$ & 10 & 7,0 \\
\hline & High education & 23 & 16,2 \\
\hline \multirow{4}{*}{ Employment } & Student & 14 & 9,9 \\
\hline & Employed & 48 & 33,8 \\
\hline & Unemployed & 17 & 12,0 \\
\hline & Retired & 63 & 44,4 \\
\hline \multirow{4}{*}{ Marital status } & Married & 65 & 45,8 \\
\hline & Unmarried partners & 32 & 22,5 \\
\hline & Single & 25 & 17,6 \\
\hline & Divorced; Widowed & 20 & 14,1 \\
\hline \multirow{2}{*}{$\begin{array}{l}\text { Participation } \\
\text { in } \\
\text { psychosocial } \\
\text { rehabilitation }\end{array}$} & Yes & 50 & 35,2 \\
\hline & No & 92 & 64,8 \\
\hline
\end{tabular}

In terms of education, majority of respondents (65.5\%) had secondary school education, and one participant reported never completing elementary school. As regards employment status, $44.4 \%$ of respondents were retired. $33.8 \%$ employed. $12 \%$ unemployed and $9.9 \%$ students. About $40 \%$ of respondents were married or have partner. Fifty subjects participated in a psychosocial rehabilitation program (PRP) while 92 did not.
Subjective quality of life was examined by domains and overall index was calculated. Table 2 provides descriptive statistics of PWI for the whole sample.

The values for the PWI show that the subjective QoL of the blind and partially sighted is within the normative range expected for the global population - between 60 and $80 \% \mathrm{SM}$. The original result for the QoL index was transposed into percentage points of scale maximum - 68.19 $\% \mathrm{SM}$ and was in keeping with said normative range. Results for life satisfaction by domain have shown that blind and partially sighted individuals were most satisfied with their close relationships ( $M=8.09 ; \mathrm{SD}=2.05)$ and least satisfied with their future security $(M=5.77 ; S D=2.53)$.

\section{Quality of life by type of visual impairment}

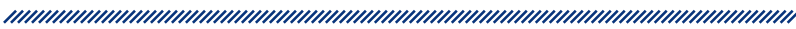

Table 3 gives the basic statistics (arithmetic mean and standard deviation) for the seven QoL subscales for the blind and partially sighted. The former was most satisfied with their close relationships ( $M=85.78 ; S D=16.98)$ while the latter with their sense of safety $(M=92.18 ; S D=23.94)$. Both groups were least happy about their future security $\left(M_{\text {low vision }}=59.06 . S D_{\text {low vision }}=23.75 ; M_{\text {blindness }}=56.67 . S D_{\text {blindness }}=\right.$ 26.56). All average subscale values for the partially sighted were higher than their counterpart average values for the blind with the exception of future security (Table 3).

Significance of the differences in PWI according to vision status (low vision and blindness) was tested by independent samples t-test. Analysis revealed statistically significant difference in the PWI according to vision status - the blind had a lower subjective QoL than the partially sighted $(t(140)=2.190 ; p<.030)$.

\section{Quality of life according to time of impairment onset}

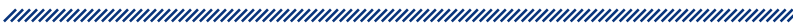

Table 4 gives descriptive statistics for the seven PWI subscales according to duration of the impairment (congenital or acquired loss of vision). As is presented both groups were most satisfied with their close relationships $\left(M_{\text {congenital }}=81.30\right.$. $S D_{\text {congenital }}=19.70 ; M_{\text {acquired }}=$ 
Table 2. Arithmetic mean. standard deviation. minimum and maximum for the seven QoL subscales and overall PWI $(N=142)$

\begin{tabular}{|c|c|c|c|c|c|c|}
\hline & M & SD & \%SM & Min & Max \\
\hline Standard of living & 6,16 & 2,37 & 61,62 & 0 & 10 \\
\hline Health & 7,01 & 2,47 & 70,07 & 0 & 10 \\
\hline Achievements in life & 7,15 & 2,13 & 71,48 & 0 & 10 \\
\hline Close relationships & 6,53 & 2,22 & 65,28 & 0 & 10 \\
\hline Safety & 8,09 & 2,05 & 80,92 & 0 & 10 \\
\hline Community connectedness & 7,02 & 2,45 & 70,21 & 0 & 10 \\
\hline Future security & 5,77 & 2,53 & 57,75 & 0 & 10 \\
\hline PWI & 6,82 & 1,61 & 68,19 & 0,86 & 10 \\
\hline
\end{tabular}

Table 3. Arithmetic mean and standard deviation for the seven PWI subscales and overall PWI for partially sighted $(n=64)$ and blind $(n=78)$ respondents

\begin{tabular}{|c|c|c|c|c|}
\hline & Partially sighted & \multicolumn{3}{|c|}{ Blind } \\
\hline Standard of living & M & SD & M \\
\hline Health & 63,28 & 20,86 & 60,26 \\
\hline Achievements in life & 71,72 & 23,13 & 68,72 & 25,95 \\
\hline Close relationships & 75,00 & 18,34 & 68,59 \\
\hline Safety & 85,78 & 16,98 & 76,92 & 23,23 \\
\hline Community connectedness & 69,06 & 19,41 & 92,18 & 23,35 \\
\hline Future security & 75,94 & 20,83 & 65,51 \\
\hline PWI & 59,06 & 23,75 & 56,67 & 26,37 \\
\hline
\end{tabular}

Table 4. Arithmetic means, and standard deviations for the seven PWI domains and overall PWI according to impairment duration; congenital $(n=69)$ vs. acquired $(n=73)$

\begin{tabular}{|c|c|c|c|c|}
\hline & \multicolumn{2}{|c|}{ Congenital } & \multicolumn{3}{c|}{ Acquired } \\
\hline & $M$ & SD & M & 25,33 \\
\hline Standard of living & 65,51 & 21,46 & 57,95 & 26,14 \\
\hline Health & 74,78 & 22,27 & 65,62 & 23,31 \\
\hline Achievements in life & 74,64 & 18,68 & 68,49 & 21,40 \\
\hline Close relationships & 81,30 & 19,70 & 80,55 & 21,09 \\
\hline Safety & 68,55 & 23,03 & 62,19 & 25,28 \\
\hline Community connectedness & 73,91 & 23,28 & 66,71 & 26,45 \\
\hline Future security & 59,86 & 23,98 & 55,75 & 16,82 \\
\hline
\end{tabular}

80.55. $\left.S D_{\text {acquired }}=21.40\right)$. and least with their sense of future security $\left(M_{\text {congenital }}=59.86 . S D_{\text {congenital }}=23.98 ; M_{\text {acquired }}=\right.$ 55.75. $S D_{\text {acquired }}=26.45$ ). All average subscale values for the congenitally blind exceeded those of respondents with acquired impairments (Table 4).
There was a statistically significant difference in PWI score between respondents with congenital and acquired visual impairments $(t(140)=2.217 ; p<.028)$. Respondents with congenital impairments reported higher QoL than was the case in acquired loss of vision. 


\section{Quality of life with respect to participation in a psychosocial rehabilitation program}

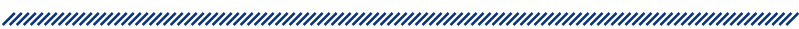

Table 5 displays descriptive statistics for the seven PWI subscales with respect to participation in a PRP. As is visible, both respondent groups were most satisfied with their close relationships $\left(M_{\text {attenders }}=81.80 . S D_{\text {attenders }}\right.$ $\left.=21.54 ; M_{\text {non-attenders }}=80.43 . S D_{\text {non-attenders }}=20.05\right)$. PRP attenders were least happy about their standard of living ( $M=62.80 ; S D=23.48)$. while non-goers were least satisfied with their sense of future security $(M=54.13$; $S D=25.43)$. All average subscale values for respondents who attended a PRP were above the average values of abstainers.

There was a statistically significant difference in the QoL between respondents who had participated in the program and those who had not. Program-goers reported higher $\mathrm{Q} o \mathrm{~L}$ than non-goers $(\mathrm{t}(140)=2.256 ; \mathrm{p}<.026)$

\section{Discussion}

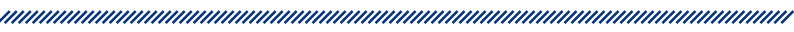

Studying the quality of life of persons with disability has become increasingly prioritized. However research into the QoL of the blind and partially sighted is scarce and limited to clinical results. The present study attempted to analyse the subjective QoL of blind and partially sighted individuals in relation to particular type of impairment, time of impairment onset and psychosocial rehabilitation.

Results of this research revealed that the QoL of the blind and partially sighted Croatians was within the theoretically expected normative range for the global population that is between 60 and $80 \% \mathrm{SM}^{21}$.Some researchers propose the "disability paradox" as one of the probable explications why persons with disabilities tend to report an average or higher-than-average quality of life despite a prevailing belief that disability degrades the quality of living. The "disability paradox" was explored by Albrecht and Devlieger ${ }^{22}$.In their paper they reported the Antonovski model where individuals strongly in touch with their disability gradually perceive their social world as rational, understandable and structured (comprehensibility). Such individuals will exert themselves to collect enough resources to help them face any problems they encounter (manageability). Ultimately they do find the meaning, values and motivation to manage disability (meaningfulness). Based on this model Albrecht and Devlieger define their model where quality of life of persons with disabilities is explained by a balance between the body, mind, and spirit. Manageability is substituted by the notion of body, comprehensibility by the notion of mind and meaningfulness by spirit. Authors found from their QoL study ${ }^{22}$ that 54.3\% of individuals with severe disability report excellent or good quality of life despite the severe disability, limited income and benefits, restricted daily activities and social isolation. Furthermore, healthy persons expressed negative attitudes towards persons with disabilities and stated believing that the quality of life of persons with

Table 5. Arithmetic means and standard deviation for the seven PWI domains and overall PWI with respect to participation in a PRP; attenders $(n=50)$ and non-attenders $(n=92)$

\begin{tabular}{|c|c|c|c|c|}
\hline & \multicolumn{2}{|c|}{ Attenders } & \multicolumn{2}{c|}{ Non-attenders } \\
\hline & M & SD & M & SD \\
\hline Standard of living & 62,80 & 23,48 & 60,98 & 23,99 \\
\hline Health & 73,20 & 25,59 & 68,37 & 24,15 \\
\hline Achievements in life & 76,60 & 17,57 & 68,70 & 22,74 \\
\hline Close relationships & 81,80 & 21,54 & 80,43 & 20,05 \\
\hline Safety & 71,00 & 20,63 & 62,17 & 22,54 \\
\hline Community connectedness & 76,00 & 22,86 & 67,07 & 24,92 \\
\hline Future security & 64,40 & 23,83 & 54,13 & 25,43 \\
\hline PWI & 72,26 & 14,76 & 65,98 & 16,39 \\
\hline
\end{tabular}


disabilities is not good. Albrecht and Devlieger's study substantiated the existence of the 'disability paradox' concluding that it appears in two forms: Firstly, despite having serious limitations in daily activities, problems in fulfilling social roles and discrimination, persons with disabilities report a good or even excellent QoL. Second form is the belief of the healthy population that persons with disabilities are not satisfied with their QoL, despite the fact that over $50 \%$ of individuals with disabilities report a good or excellent QoL as the result of control over their body, mind and spirit, as well as approach to life. It is believed that persons with disabilities cannot be satisfied with their health or have a high quality of life just by being restricted in their functioning not being capable of fulfilling their life roles and consequently suffering from social stigma and isolation. Someone with disability has to exert oneself to achieve personal satisfaction. The "disability paradox" stresses the importance of personal experience in defining oneself, one's world view and social relationships. However, not all share this perception. Whether or not a person has similar experience depends on any negative tendencies in the attitudes and expectations of the public and health professionals towards individuals with disabilities. Numerous studies reported that persons with disabilities may have a much more positive self-image than healthy persons surrounding them. Negative predispositions, perception and contradictory behaviour towards persons with disabilities are associated with the general population's prejudice that the QoL of persons with disabilities cannot be as high as that of the healthy individuals, regardless of the "disability paradox". Human nature implies accepting and adapting to change, and there is more to quality of life than just health. When it comes to QoL of the population with disabilities it should not be restricted to just the health domain ${ }^{23}$. The results of the present research go in favour of that finding. It was demonstrated that the blind and partially sighted were most satisfied with their close relationships while they were least satisfied with future security. The more affection, care, and compassion one receives from one's immediate environment one's satisfaction with the quality of one's life grows. A conclusion can be made that the QoL of the blind and partially sighted is greatly affected by their close relationships. The same finding was reported by other studies where the family and friends domain proved to be the most important for the quality of life ${ }^{12}$. A sense of future security is most likely affected by the social condition and poor socioeconomic status of the majority Croatian population but also by a generally low social status of the visually challenged people. They have been neglected in the community and are not competitive in the labour market which renders their future insecure. Currently, the blind and partially sighted in Croatia can be hired for but a few positions (telephone operators, administrators and administrative secretaries) which are not the career choice for most of persons with disabilities due to either job specificities or relatively poor hiring opportunities ${ }^{24}$. Also the process of hiring individuals with visual impairments does not stand good chances without suitable legal background. Employment of the blind and partially sighted often implies a loss of certain benefits ${ }^{24}$.The $68.19 \%$ result of the scale minimum can be interpreted as going in favour of the homeostatic model according to which different unfavourable factors such as physical disease, lead to a temporary degradation of QoL. This drop is only temporary though as certain mechanisms aim to bring the subjective perception of life quality back to the initial level. Though this study did not cover the respondents' quality of life prior to or immediately after disease onset it may be assumed that their QoL was somewhat degraded after disease onset but that it eventually regained balance ${ }^{25}$. Significant events and severe conditions such as disease or disability may temporarily destabilize the homeostasis but in many cases the self-assessed quality of life tends to return to the initial level over time. Moreover, it became evident that only specific conditions such as strong chronic pains lead to a permanent and significant drop in the self-perceived QoL. In other words, disability most commonly does not result in permanent degradation in the subjective quality of life as individuals eventually focus on other values and areas to compensate for incurred losses ${ }^{26}$. One's quality of life does not primarily depend on the benefits or shortcomings one might experience but rather on one's own ability to compensate for the drawbacks and make best of what advantages one has ${ }^{27}$.

Results of this research revealed statistically significant difference in the average PWI score according to the vision status; blind individuals reported a lower subjective QoL than the partially sighted. The outcome is in keeping with the expectations as well as references ${ }^{12,28}$. The blind people have more difficulty with taking care of themselves than the partially sighted who probably have to thank what sight they have left. Residual vision in partially sighted persons aside from being correlated with a higher QoL is also connected with less social isolation and difficulty with fulfilling life roles ${ }^{12}$. Crewe et al. ${ }^{28}$ found that, aside from having better QoL, 
the partially sighted also have less problems moving around recognizing objects and reading than the blind. Partially sighted individuals were expressly most satisfied with their close relationships which supports Pey, Nzegwu and Dooley's ${ }^{12}$ finding, that they have less problems with establishing and maintaining social relationships. The blind felt most satisfaction with their feeling of safety. A question was raised of how the respondents understood the notion of safety. Often they asked for additional explanation. Many read it as safety in the sense of movement, running into people, falling down accidents while walking and clumsiness. However, authors of the PWI questionnaire describe the sense of safety as a general feeling of safety within the environment where the respondents live without stressing any physical faculties such as insecure walk. Both respondent groups were least satisfied with future security.

Significant difference in PWI was found between persons with congenital and those with acquired visual impairments. The former had a statistically higher QoL than the latter. Obtained results match both the expectations and listed references ${ }^{11,14,15}$. Persons who are blind from birth or most of their lives tackle their problems more easily ${ }^{11,12}$. Patients who went blind later in life go through a series of phases of acceptance of and adjustment to the new situation which the former most likely skip just by learning to accept their life and disability from birth. Later onset of visual impairments is much harder to accept. Patients usually report having to go through a state of shock, fear and panic, wanting their life to remain unchanged and resisting rehabilitation. The fact remains that loss of vision does most certainly affect their lives. The stages they go through are affected by strong emotions (most profoundly by sense of loss) and wishing to have their sight back. Many never manage to adapt and lose their autonomy ${ }^{15}$. Parrish $^{14}$ found that, after being diagnosed with glaucoma, patients went through a change in the subjective perception of QoL not just on account of disease but also as a result of anxiety caused by diagnosis itself. Both respondent groups were most satisfied with their close relationships, least with their sense of future security.

Apropos the fourth hypothesis which was confirmed with significantly higher QoL of those who participated in a PRP in comparison to those who did not. Psychosocial rehabilitation proved to help reach statistically significantly higher values of QoL in program attendees as opposed to non-goers $(p<.05)$. The outcome is as expected and as referenced ${ }^{11,16}$. It testifies in favour of psychosocial rehabilitation by demonstrating that it improves the quality of life and independence of the individual within the family and the working environment ${ }^{11}$. Psychosocial rehabilitation was designed for persons with severe congenital and acquired visual impairments which caused certain changes in the family, personal life, physical space and society ${ }^{29}$.

Of the seven domains that were tested for satisfaction, both groups were most satisfied with their close relationships. One of the main objectives of psychosocial rehabilitation is to empower a person for social integration. In other words, the prerequisite for social integration is good social development and internalization of social skills. Possessing social skills makes communication with others easier. It is particularly this area that the visually challenged have problems with. To realize the above aim, the environment must be receptive and supportive, and the individual with visual impairments capacitated and motivated to become an active and full member of their social community. Respondents who were given the opportunity to attend a PRP were least happy with their standard of living. This outcome can be explained by the fact that psychosocial rehabilitation cannot improve one's standard of living and that if someone is not happy with their standard, this sentiment will not change after rehabilitation.

Standard of living is approached as a desirable degree of fulfilment of material and non-material needs, i.e. the level of wellbeing available to an individual or a group of people. Standard of living in general is defined by indicators such as actual income per person and poverty rate ${ }^{30}$. Respondents who did not have the opportunity of attending a PRP were least satisfied with their feeling of future security. Due to not experiencing psychosocial rehabilitation it is possible that they could not adapt to their disability or they could feel insecure about their future. It has already been discussed that the visually challenged are less competitive on the labour market which leads to feeling insecure about one's future and those who were not given the opportunity of psychosocial rehabilitation or were insufficiently attentive in the program may be less keen on looking for work even despite a hypothetically competitive educational background ${ }^{31}$.

\section{Implications, limitations and future research}

The population with visual impairments is very heterogeneous in terms of diverging diagnoses, times of impairment onset, chronological ages, education, 
competences (rehabilitated or not, moving independently using a cane or guide dog), skills of handling print (Braille, big print) and IT equipment, employment and previous experiences. Precisely this heterogeneity caused one of the biggest problems for the present research: non-uniform mode of data collection on account on population diversity. This combined approach to data collection was applied to make it easier for interviewees to fill out questionnaires. Consequently, the results could not be obtained under identical conditions. Respondents using online questionnaires had no one to ask for clarification, though they had been emailed contact-data of a researcher to get in touch with, if needed. Online interviewing did however, escape the trap of externally suggesting a socially desirable answer in the presence of a researcher. This was not the case in on-the-spot questionnaires where there was the risk of choosing socially desirable answers in the presence of attendants but also the risk of feeling embarrassed to provide true answers. Still, socially conditioned answers and reluctance to give true answers are not necessarily dependent upon researcher presence but rather on the prejudice among the healthy population regarding the visually impaired and their capacities. It is possible that the respondents wished to portray their QoL higher than it actually was. Also the fact that the respondents had been contacted through associations and that it had mostly been active members who were present in association premises in the first place must be duly noted. Said respondents may have been less socially isolated and more engaged in their social community, which consequently could partly explain why the QoL of the blind and partially sighted falls within the theoretically forecasted normative range.

One of the recommendations for a study follow-up would be to include the residence variable as it would surely supply interesting results when it comes to the quality of life of the blind and partially sighted population. Living in the country is never the same as living in a city even where it concerns the healthy population. Most definitely, researchers should take into account other life quality-related characteristics, such as marital status, education or employment. Studies have shown that as a rule. Persons formally married or living in a common-law partnership report better personal QoL than singles ${ }^{32}$. It was demonstrated that marital status is one of the most significant predictors of subjective wellbeing. Married individuals also report better mental health ${ }^{33}$. Likewise, better education has been associated with higher life satisfaction ${ }^{21}$. When it comes to unemployment results have shown that the level of satisfaction of unemployed individuals is drastically lower than that of employed persons. An extensive British study demonstrated than unemployment lowers the subjective wellbeing more than any other variable $^{34}$. Quality of life refers to different areas, and for this reason the impact of restrictions on the QoL of a person should first be studied.

Regarding the psychosocial rehabilitation intervention success should be analysed whether or not it truly contributes to QoL, or just seems to do so, QoL should be examined before and after psychosocial rehabilitation to measure and upgrade the success of such programs.

As past research was limited to clinical results, and by extension, QoL was limited to the health domain the measuring of subjective QoL of blind and partially sighted persons should be based on generic, not disease- or impairment-specific, measuring instruments. Such instruments should be adapted to persons with disabilities. To illustrate when addressing blind persons, the 'safety' notion should be further clarified or rephrased to be better understood by the target population as they most likely do not define it in the same way the sighted population does. However, the most significant findings should come through a well construed longitudinal research which provides safer conclusions on data causality. Transversal studies do not provide clear insight into data causality ${ }^{33}$. Given the deficit of similar studies and the research pattern it is recommended to carry out a more extensive research which could provide more detailed information.

\section{Conclusions}

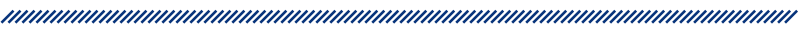

Research have shown that the subjective QoL of the blind and partially sighted people matches the theoretically expected normative range for the global population of 60-80 \%SM. Type and duration of impairment as well as participation in a PRP are significant indicators of subjective QoL of the visually challenged. As expected a difference was found in the quality of life according to impairment type. Persons suffering from low vision reported better QoL than the blind. Furthermore, a difference in QoL was found between persons with visual impairments in dependence on the onset 
of impairment. Congenital blindness namely implied better QoL than acquired blindness. Also differences in QoL were found between the visually impaired persons depending on having attended a PRP or not. Program goers reported better QoL than non-goers. The results of this study have significant theoretical and practical implications to be applied applicable. Further research that will consider the shortcomings of the present study is needed.

\section{References}

1. Stančić V. Visual impairment. Biopsychosocial aspects. Impresum. Zagreb: Školska knjiga, 1991. Croatian.

2. World Health Organization. International Classification of Diseases. 10th Revision (ICD 10). Geneva (Switzerland); 2010. [Internet] Available from: http://apps.who.int/classifications/icd10/browse/2010/en\#/H53-H54 (accessed 29 Oct 2012).

3. World health organisation. Visual impairment and blindness. 2012. [Internet] Available from: http://www.who.int/ mediacentre/factsheets/fs282/en/ (accessed 29 Oct 2012).

4. Kocur I, Resnikoff S. Visual impairment and blindness in Europe and their prevention. British Journal of Ophthalmology. 2002;86(7):716-722. [Internet] Available from: (https://www. ncbi.nlm.nih.gov/pmc/articles/PMC1771203/) (accessed 29 Oct 2012).

5. Benjak T, Runjić T, Bilić Prcić A. The prevalence of visual impairment in the Republic of Croatia on the basis of the data of the Croatian Register of Persons with Disabilities. Hrvatski časopis za javno zdravstvo. 2013;9(35):335-339. [Internet] Available from: http://www.hcjz.hr/index.php/ hcjz/article/view/227 (accessed 29 Oct 2012). Croatian.

6. United Nations. Convention on the Rights of Persons with Disabilities. 2008. [Internet] Available from: http://www. un.org/disabilities/convention/conventionfull.shtml (accessed 29 Oct 2012).

7. Langelaan M. Quality of life of visually impaired working age adults. Enschede: PrintPartnerslpskamp; 2007.

8. Verdugo MA, Prieto G, Caballo C, Peláez A. Factorial Structure of the Quality of Life Questionnaire in a Spanish sample of visually disabled adults. European Journal of Psychological Assessment. 2004;(21)1:44-55.

9. Leplége A, Schemann JF, Diakité B, Touré O, Ecosse E, Jaffré $Y$, Dumestre G. A new condition specific quality of life measure for the blind and partially sighted people in sub-Saharan Africa. The IOTAQOL: Methodological aspects development procedure. Quality of life research. 2006;15:1373-1382.
10. Langelaan M, de Boer MR, van Nispen RM, Wouters B, Moll AC, van Rens GH. Impact of visual impairment on quality of life: a comparison with quality of life in the general population and with other chronic conditions. Ophthalmic Epidemiol. 2007;14(3):119-26.

11. Amini R, Shojaee H, Haghani H, Masoomi M, Davarani $\mathrm{HH}$. Physical Injuries and Quality of Life in Blind War Survivors: A Cross-sectional Study. Archives of Iranian Medicine. 2010;13(6):504-508.

12. Pey T, Nzegwu F, Dooley G. Functionality and the Needs of Blind and Partially-Sighted Adults in the UK: An Interim Report. 2006. [Internet] Available from: http://www. guidedogs.org.uk/fileadmin/gdba/images/downloads/ rehabsteering/UK_Interim_Report_-_Nov_06_-_Latest_ Draft.pdf (accessed 29 Oct 2012).

13. Massof RW. Low vision and blindness: changing perspective and increasing success. Braille Monitor; 2006. [Internet] Available from: https://nfb.org/images/nfb/publications/ bm/bm06/bm0610/bm061005.htm (accessed 29 Oct. 2012).

14. Parrish RK. Visual impairment, visual functioning and quality of life assessments in patients with glaucoma. Transactions of the American Ophthalmological Society. 1996;94:919-1028.

15. Thurston M. An inquiry into the emotional impact of sight loss and the counselling experiences and needs of blind and partially sighted people. Counselling and Psychotherapy Research. 2010;10(1):3-12.

16. Langelaan M, van Nispen RMA, de Boer MR, Wouters B, Moll AC, van Rens GHMB. Change in quality of life after rehabilitation: prognostic factors for visually impaired adults. Enschede: PrintPartnerslpskamp; 2007.

17. Mršić V. Orientation and mobility in Croatia: training for blind and visually impaired people to move independently. Zagreb: Croatian Association of Guide Dog and Mobility; 1995. Croatian.

18. International Wellbeing Group. Personal Wellbeing Index. Melbourne: Australian Centre on Quality of Life, Deakin University; 2013.

19. International Wellbeing Group. Personal Wellbeing Index: 5th Edition. Melbourne: Australian Centre on Quality of Life, Deakin University; 2013. [Internet] Available from: http://www.deakin.edu.au/research/acqol/instruments/ wellbeing-index/index.php (accessed 29 Oct. 2012).

20. Diener E, Emmons RA, Larsen RJ, and Griffin S. The Satisfaction with Life Scale. Journal of Personality Assessment. 1985;49:71-75.

21. Cummins RA. Normative life satisfaction: Measurement issues and a homeostatic model. Social indicators research. 2003;64(2),225-256.

22. Albrecht GL, and Devlieger PJ. The disability paradox: high quality of life against all odds. Social Science \& Medicine. 1999;48:977-988.

23. Ameratunga S. Disability counts - or does it? Guest editorial. Injury Prevention. 2005;11:129-130.

24. Runjić T, Bilić A, Znaor M. Employment of persons with visual impairments. International symposium -actuality 
and perspectives of employing persons with disabilities. Zagreb; 2001. Croatian.

25. Markanović D, Jokić-Begić N. Kvaliteta života u zdravlju i bolesti. In: Vuletić G, ed. Kvaliteta života i zdravlje - electronic edition. Osijek: Faculty of humanities and social sciences, University in Osijek \& Croatian Science Foundation; 2011. Croatian.

26. Vuletić $\mathrm{G}$, Ivanković $\mathrm{D}$, Davern M. Kvaliteta života u zdravlju i bolesti. In: Vuletić G, ed. Kvaliteta života i zdravlje - electronic edition. Osijek: Faculty of humanities and social sciences, University in Osijek \& Croatian Science Foundation; 2011. Croatian.

27. Krizmanić M, Kolesarić V. Attempts to conceptualize "Quality of life". Applied psychology. 1989; 10: 179 -184. Croatian.

28. Crewe JM et al. Quality of life of the most severely visionimpaired. Clinical and Experimental Ophthalmology. 2011;39:336-343.

29. Association of the Blind. The blind and partially sighted people. 2012. [Internet] Avaliable from: http://www.savez- slijepih.hr/hr/kategorija/slijepe-osobe-100/ (accessed 29 Oct 2012). Croatian.

30. Cvrlje D, Ćorić T. Macro \& micro aspects of standard of living and quality of life in a small transition economy: The case of Croatia. Faculty of Economics and Business University of Zagreb; 2010. [Internet] Available from: http:// web.efzg.hr/RePEc/pdf/Clanak\%2010-02.pdf (accessed 14 Nov 2012). Croatian.

31. Stančić V, Tonković F, Zovko G. Profesionalna integracija slijepih. Zagreb: Fakultet za defektologiju; 1979. Croatian.

32. Mellor D, Stokes M, Firth L, Hayashi Y, Cummins R. Need for belonging, relationship satisfaction, loneliness, and life satisfaction. Personality and Individual Differences. 2008;45 (3):213-218.

33. Penezić Z. Zadovoljstvo životom odraslih osoba: kroskulturalna perspektiva. In: Lacković-Grgin K, Ćubela Adorić V, eds. Odabrane teme iz psihologije odraslih. Jastrebarsko: Naklada Slap; 2006. Croatian.

34. Frey B, Stutzer A. What can economists learn from happiness research? Journal of economic literature. 2002;40:402 - 435. 


\section{KVALITETA ŽIVOTA SLIJEPIH I SLABOVIDNIH OSOBA}

1 Gorka Vuletić

2 Tea Šarlija

3 Tomislav Benjak

1 Odsjek za psihologiju, Filozofski fakultet u Osijeku, Lorenza Jaegera 9, 31000 Osijek, Hrvatska

2 Centar za socijalnu skrb Donji Miholjac, Vukovarska 7, 31540 Donji Miholjac, Hrvatska

3 Hrvatski zavod za javno zdravstvo, Rockefellerova 7, 10000 Zagreb, Hrvatska

\section{Sažetak}

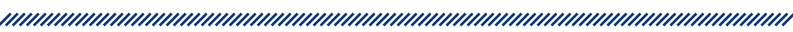

Cilj ovog istraživanja bio je ispitati subjektivnu kvalitetu života slijepih i slabovidnih osoba u odnosu na vrstu oštećenja vida, trajanje oštećenja te sudjelovanje u programu psihosocijalne rehabilitacije. $U$ istraživanju je primijenjen sociodemografsko-zdravstveni upitnik, a kako bi se ispitalo zadovoljstvo sudionika pojedinim domenama života primijenjen je Indeks osobne kvalitete života za odrasle. Rezultati ovog istraživanja pokazuju da je subjektivna kvaliteta života slijepih i slabovidnih osoba u okviru teorijski očekivanoga normativnog raspona za svjetsku populaciju od 60 do $80 \%$ skalnog maksimuma. Rezultati pokazuju da su vrsta oštećenja vida, trajanje oštećenja te sudjelovanje u psihosocijalnoj rehabilitaciji važni indikatori subjektivne kvalitete života slijepih i slabovidnih osoba.
Ključne riječi: oštećenje vida, sljepoća, slabovidnost, subjektivna kvaliteta života, trajanje oštećenja, psihosocijalna rehabilitacija 